\title{
Biomedical trust fund is proposed to support basic research at NIH
}

\begin{abstract}
Washington. Two prominent US senators have proposed a trust fund that would provide billions of dollars a year for biomedical research from a tax on each insurance policy written under any reform of the US health care system.
\end{abstract}

More than a hundred professional societies and disease support groups have endorsed the idea, excited by the thought of more money for their members and pleased that it places research at the centre of attempts to reduce the cost of health care, which this year will exceed $\$ 900$ billion. However, the proposal appears at this point to be more of an angry response to the budget that President Bill Clinton has proposed for the US National Institutes of Health (NIH) than a comprehensive, long-term approach to improving public health.

At a press conference last week to announce their proposal, Senators Tom Harkin (Democrat, Iowa) and Mark Hatfield (Republican, Oregon) described the failure of biomedical research funding to keep pace with the health needs of the US public. The trust fund, they said, could raise NIH's current annual budget of $\$ 10.3$ billion by as much as 50 per cent.

"Until we adopt this approach", says Harkin, who is chairman of the Senate appropriations subcommittee that reviews the NIH budget, "the health care debate will be about paying bills, not preventing them". Adds Hatfield, "the ultimate cost savings in health-care reform is prevention, and the best approach is through research".

The trust fund would be derived from a $\$ 5$ tax on each health insurance premium paid under any new health care system and would supplement the annual NIH appropriations, explained Hatfield, the senior minority member of the appropriations subcommittee. That goal could be met with a provision that the trust fund would be tapped only after each institute received a certain minimum level of funding, adjusted annually to account for inflation.

Testifying the previous day before Harkin's subcommittee, outgoing NIH director Bernadine Healy said that she would like to see the money used to raise the number of grants awarded each year from a current level of 21,500 to about 32,000 . The infusion of money would also increase the chance of having a worthwhile idea funded, she said, raising success rates from a projected 21 per cent in 1994 to 33 per cent by 1997.

"This would be a signal to the community that we had reached a sustainable level of support that can meet the tremendous opportunities we face", she said. Any addi- tional money, she added, "would focus on neglected areas such as career training and the growing problem of aging research facilities".

Healy also disclosed that her initial 1994

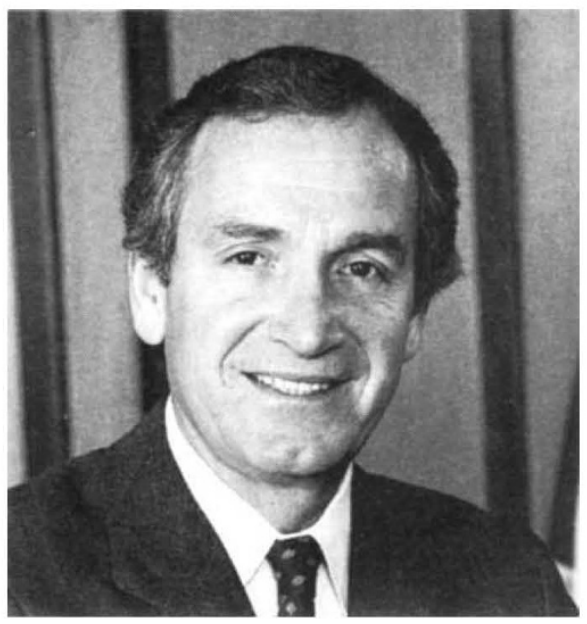

Harkin puts his trust in research.

budget request was $\$ 12.3$ billion, a $\$ 2$ billion increase endorsed by her political bosses at the Department of Health and Human Services but ignored by the new Clinton administration. "We proposed two years of 18 per cent increases, followed by increases

of 14 per cent and 6 per cent", she said. "And for the first time in its history, the department accepted our full request and passed it along to OMB [the White House Office of Management and Budget]."

Several months later, when the new administration examined NIH's request, she said, the agency was told to develop a budget that matched a projected 4 per cent rate of inflation, which was later amended to a 3.2 per cent, across-the-board increase that made exceptions for a handful of programmes. "We were not even at the table when the final budget was put together", she added, "and we weren't allowed to appeal. Instead, we were told how much to put into each special initiative - for AIDS, breast cancer, high-performance computing and advanced materials."

Harkin and Hatfield say that they are not wedded to a tax of a specific size or even to the idea of a trust fund itself. Instead, they say that their goal is to make sure that the task force assembling the reform plan, led by the president's wife, Hillary Rodham Clinton, recognizes the importance of biomedical research and gives it a prominent place in its final proposal. Harkin said that Clinton and his aides had no specific reaction when he described the idea to them in a series of discussions over the past two months.

Jeffrey Mervis

\section{Life sciences take a dive}

Washington. The life sciences have been demoted within the US Office of Science and Technology Policy (OSTP), a move that has upset biomedical researchers and even caught the eye of an influential Democratic senator.

John Gibbons, director of OSTP and presidential science adviser, has reorganized his office to give greater attention to environmental issues, and Robert Watson, a NASA scientist, is preparing to join the office as the new associate director for environment. But because OSTP is allowed only four associate directors, one of the existing posts had to be refigured, and the life sciences lost out. That outcome is not new to those in the discipline: historically, the science adviser is a physicist and the office concentrates on matters of national security and technology.

Under the new alignment, the associate directors for the physical sciences and the life sciences will be combined under a single associate director for science. Gibbons says that he is looking for someone with broad research experience to fill the science post, and that the life sciences and the physical sciences will be handled by assistant directors within that office.

A third associate directorship, for technology, has been filled by Skip Johns, whom Gibbons brought with him from the congressional Office of Technology Assessment. The fourth associate director, not yet named, will cover national security and international affairs.

The restructuring is sure to displease Senator Tom Harkin (Democrat, Iowa), the chairman of the appropriations subcommittee that reviews the NIH budget and an advocate for greater spending on biomedical research (see above). Last week, at a hearing on the 1994 budget for the National Institutes of Health (NIH), Harkin talked about the need "to elevate our voices" and asked if there was a life scientist "at the elbow" of the science adviser, who is a physicist. "It is my understanding that there is not", replied Bernadine Healy, director of NIH.

Jeffrey Mervis 